\title{
Interactive Effects of Planting Date and Cultivar on Tomato Spotted Wilt of Peanut
}

\author{
A. K. Culbreath, Professor, Department of Plant Pathology, The University of Georgia Coastal Plain Experiment \\ Station, Tifton 31793-0748; B. L. Tillman, Assistant Professor, Agronomy Department, The University of Florida, \\ Marianna 32446; R. S. Tubbs, Assistant Professor, Department of Crop and Soil Sciences, J. P. Beasley, Jr., Profes- \\ sor, Department of Crop and Soil Sciences, R. C. Kemerait, Jr., Associate Professor, Department of Plant Pathol- \\ ogy, and T. B. Brenneman, Professor, Department of Plant Pathology, The University of Georgia Coastal Plain Ex- \\ periment Station, Tifton 31793-0748
}

\begin{abstract}
Culbreath, A. K., Tillman, B. L., Tubbs, R. S., Beasley, J. P., Jr., Kemerait, R. C., Jr., and Brenneman, T. B. 2010. Interactive effects of planting date and cultivar on tomato spotted wilt of peanut. Plant Dis. 94:898-904.

Field experiments were conducted at Gainesville and Marianna, FL in 2004 and 2005 in which severity of spotted wilt, caused by Tomato spotted wilt virus, and pod yield were compared in six peanut (Arachis hypogaea) cultivars. The six cultivars included the moderately field resistant cultivars ANorden, C-99R, and Georgia Green; the highly field resistant cultivars AP-3 and DP-1; and the susceptible cultivar SunOleic 97R. There were four trials at each location, with four planting dates that ranged from late March to early June. Tomato spotted wilt severity in moderately resistant and susceptible cultivars was lower at Gainesville than at Marianna in both years in moderately resistant and susceptible cultivars. Trends in incidence for the two locations were less evident for AP-3 and DP-1. At Gainesville, there were few differences in tomato spotted wilt severity, and severity ratings were similar for Georgia Green and SunOleic 97R in two of four trials in 2004 and across all trials in 2005. At Marianna, severity ratings were lower for Georgia Green than for SunOleic 97R in six of the eight trials, and severity of tomato spotted wilt was lower for AP-3, C99R, and DP-1 than for Georgia Green in all eight trials. In 2004, there was a trend toward decreasing severity ratings for Georgia Green and SunOleic 97R with later planting dates, but not for AP-3 or DP-1 at Marianna. Split-plot field experiments were also conducted at Tifton, GA in 2005 through 2007 in which incidence of tomato spotted wilt and pod yield were compared for peanut cultivars AP-3 and Georgia Green across planting dates ranging from late April through late May. Incidence of tomato spotted wilt was lower for AP-3 than for Georgia Green within each planting date of all years, and planting date effects were smaller in AP-3, if observed at all, than in Georgia Green. In most planting dates of all three trials, yields were higher for AP-3 than for Georgia Green. The relationships between yield and planting date were not consistent. These results indicate that the level of field resistance in AP-3 and DP-1 cultivars is sufficient to allow planting in late April without greatly increasing the risk of losses to tomato spotted wilt.
\end{abstract}

In recent years, integrated disease management programs combining use of field resistant cultivars with suppressive cultural practices and in-furrow application of phorate insecticide have been very successful in managing tomato spotted wilt, caused by Tomato spotted wilt virus (TSWV), of peanut (Arachis hypogaea L.) in the southeastern United States $(4,10)$. Planting Georgia Green (1), a runner-type cultivar with a moderate level of field resistance to TSWV, has been a key factor in management of spotted wilt throughout much of the region. The level of resistance in Georgia Green is not high enough to

Corresponding author: A. K. Culbreath

E-mail: spotwilt@uga.edu

Accepted for publication 2 April 2010.

doi:10.1094/PDIS-94-7-0898

(C) 2010 The American Phytopathological Society prevent severe epidemics of tomato spotted wilt (8). However, Georgia Green yields often respond positively to other practices that suppress spotted wilt epidemics $(2,9)$. With moderately resistant cultivars, it is often essential to use integrated management programs that combine as many factors that suppress spotted wilt as possible to minimize losses to the disease.

Planting date is one factor that can have a huge impact on spotted wilt epidemics in peanut $(4,10,11,18)$. In the southeastern United States, peanut planted in middle to late May typically is at a much lower relative risk of losses to spotted wilt than peanut planted in April or early May (4). Because of this, there has been a major shift to later planting for much of the peanut crop compared with years before tomato spotted wilt became a problem (10). However, other factors such as the weather, hectarage to be planted, equipment limitations, and other crops to be harvested or planted during peanut planting season also affect when a grower can plant or would prefer to plant peanut. In addition, planting over a wider range of dates can help with the logistics of harvest and curing of the peanut crop. Therefore, it is desirable and often necessary for many growers to begin planting well before the dates that are optimum for managing tomato spotted wilt. The ability to plant in April or early May without increased risk of losses to spotted wilt would be an advantage to growers who have large hectarage to plant or who need to plant other crops later in May.

Higher levels of field resistance in new peanut cultivars may allow more flexibility in spotted wilt management programs. Several new cultivars with higher levels of field resistance to TSWV than Georgia Green are now available $(7,9)$. The cultivars AP-3 (14) (tested previously as F90/73-5-1-b2-B [12]) and DP-1 (15) (tested previously as F86/43-1-1-1-1-1-b2-B [12]) are runner type cultivars released by the University of Florida that have among the highest levels of field resistance to TSWV in available cultivars $(4,6,9)$. AP-3, DP-1, and several other new cultivars and breeding lines have performed well in experiments where April and early May planting dates have been used to maximize potential for spotted wilt epidemics $(9,12,19)$. However, direct comparisons of how these and other highly resistant cultivars perform relative to the standard cultivar Georgia Green across a range of planting dates have not been reported.

The primary objective of this work was to compare the effects of Georgia Green and newer peanut cultivars on tomato spotted wilt epidemics across a range of planting dates, with particular emphasis on determining whether field resistance in AP-3 and DP-1 is sufficient to allow planting during times that typically represent higher risks of damage by tomato spotted wilt.

\section{MATERIALS AND METHODS}

Gainesville and Marianna, FL. Field experiments were conducted in Gainesville and Marianna, FL in 2004 and 2005 to compare tomato spotted wilt severity in six cultivars across four planting dates. Contiguous quadrats of the same field were used for the four planting dates. Planting 
dates were not replicated and were randomly assigned to the quadrats. Within each planting date, peanut cultivars ANorden, AP-3, C-99R, DP-1, Georgia Green, and SunOleic $97 \mathrm{R}$ were compared in a randomized complete block experiment with three replications. As previously introduced, AP-3 and DP-1 are cultivars with high levels of field resistance to TSWV. C99R, ANorden, and Georgia Green have moderate levels of field resistance, with $\mathrm{C}$ $99 \mathrm{R}$ being reported to be more resistant than Georgia Green and intermediate between Georgia Green and DP-1 (12,21). SunOleic 97R is susceptible to TSWV $(12,19)$.

Planting dates at Gainesville were 15 April, 4 May, 25 May, and 15 June 2004 and 29 March, 19 April, 10 May, and 2 June 2005. Planting dates at Marianna were 22 April, 6 May, 20 May, and 7 June 2004 and 19 April, 4 May, 19 May, and 6 June 2005. Each trial within a year and location henceforth will be referred to by the planting date.

Plots were $4.6 \mathrm{~m}$ long, separated by $3-\mathrm{m}$ alleys. Peanut seed were planted in $91-\mathrm{cm}-$ spaced single rows at a rate of 19.6 seed per meter of row. Soil types were Candler sand (Hyperthermic, uncoated Typic Quartzipsamments) at Gainesville and Chipola loamy sand (loamy, kaolinitic, thermic Arenic Kanhapludult) at Marianna. Fields were planted to bahiagrass (Paspalum notatum Flugge) the preceding year at Gainesville and cotton (Gossypium hirsutum L.) the previous year at Marianna. The Gainesville location had a history of mild epidemics of tomato spotted wilt in peanut, whereas disease history of the Marianna location included severe epidemics of tomato spotted wilt.

Tifton, GA. Field experiments were conducted at the University of Georgia Coastal Plain Experiment Station, Lang Farm and Rigdon Farm, Tifton, GA in 2005 through 2007. Soil type was a Tifton loamy sand (fine-loamy siliceous, thermic Plinthic Kandiudult). Fields were planted to cotton the preceding year and to peanut 2 years prior, both grown with conventional tillage. Disease history of fields included severe epidemics of tomato spotted wilt in peanut.

The experimental design was a split-plot with four replications. Whole plot treatments consisted of planting dates, and subplot treatments consisted of two cultivars, Georgia Green and AP-3. Plots were $14.6 \mathrm{~m}$ long, separated by $2.4-\mathrm{m}$ alleys. Peanut seed were planted in $91-\mathrm{cm}$-spaced single rows at a rate of 15 seed per meter of row. Planting dates were 3 May, 13 May, and 23 May 2005; 24 April, 2 May, 8 May, 16 May, and 23 May 2006; and 25 April, 1 May, 9 May, 16 May, and 24 May 2007.

General plot maintenance. For trials in Georgia, acephate (Orthene 75W, Valent U.S.A. Corporation, Walnut Creek, CA) at $0.84 \mathrm{~kg}$ a.i. ha $^{-1}$ was applied 13 days after planting (DAP) in all years to suppress early season feeding injury caused by larvae of tobacco thrips (Frankliniella fusca Hinds). Severe thrips feeding injury complicates early-season evaluations of tomato spotted wilt. Applications of acephate typically have had little effect on incidence of tomato spotted wilt in Georgia (20). For all trials in Florida and Georgia, plot maintenance included treatment with herbicides to minimize weed competition, fungicides to minimize foliar and soilborne fungal diseases, and insecticides, in addition to acephate mentioned previously, to minimize damage by insects as needed according to the respective University of Florida Extension and University of Georgia Extension recommendations. Soil preparation for all locations utilized conventional tillage that included disk harrowing and moldboard plowing in the early spring.

All trials were irrigated as needed to supplement rainfall so that plants were not stressed for water. With supplemental irrigation, environmental conditions in all years and locations were conducive for peanut growth and good to excellent yield potential. However, in 2004, both Gainesville and Marianna locations received excessive rainfall during September and early October. During the period from 4 September to 4 October 2004, rainfall totals were $51.1 \mathrm{~cm}$ at Gainesville and $25.4 \mathrm{~cm}$ at Marianna (http://fawn.ifas.ufl.edu/). A rainy period also occurred late in the season at Gainesville in 2005. From 28 September to 8 October 2005, rainfall totals were $14.4 \mathrm{~cm}$ at Gainesville, with rainfall of $0.25 \mathrm{~cm}$ or greater recorded on 7 of the 10 days (http://fawn.ifas.ufl.edu/).

Disease assessment. Marianna and Gainesville. Tomato spotted wilt was evaluated 1 or 2 days prior to digging each cultivar based on its relative maturity. The relative maturity of cultivars is as follows: DP-1 and C-99R, late ( 150 days from planting to maturity); ANorden, Georgia Green, and SunOleic 97R, medium ( 135 days from planting to maturity); and AP-3, intermediate $(\sim 140$ days from planting to maturity). Severity of tomato spotted wilt was rated for each plot using a 1 to 10 scale where $1=$ no disease and $10=$ all plants severely diseased (19).

Tifton. Tomato spotted wilt was evaluated in all plots on 22 June, 27 July, 8 August, and 29 August 2005; 23 June, 26 July, 23 August, and 5 September 2006; and 2 July, 26 July, 17 August, and 6 September 2007. Incidence of tomato spotted wilt was determined by counting the number of $0.3-\mathrm{m}$ portions of row containing severely stunted, chlorotic, wilted, or dead plants for each plot and converting that number to a percentage of total row length (13).

Pod yields. In the Florida trials, cultivars were dug and inverted based on their relative maturity (approximate average days to maturity) as indicated previously, except that AP-3 was dug at the same time as ANorden, Georgia Green, and SunOleic
97R in Gainesville trials and at the same time as ANorden and Georgia Green in 2005 at Marianna. In 2004 in Gainesville, ANorden, Georgia Green, SunOleic 97R, and AP-3 were dug 30 August, 16 September, 7 October, and 27 October, and C99R and DP-1 were dug 13 September, 4 October, 27 October, and 10 November for the four respective planting dates. In 2005 in Gainesville, ANorden, Georgia Green, SunOleic 97R, and AP-3 were dug 15 August, 2 September, 26 September, and 10 October, and C-99R and DP-1 were dug 29 August, 15 September, 6 October, and 10 October for the respective planting dates.

In 2004 in Marianna, ANorden, Georgia Green, and SunOleic 97R were dug and inverted 3 September, 20 September, 4 October, and 18 October, and AP-3 was dug and inverted 10 September, 24 September, 4 October, and 29 October for the four respective planting dates. C-99R and DP-1 were dug and inverted 20 September, 4 October, 18 October, and 29 October for the respective planting dates. In 2005 at Marianna, plots of SunOleic 97R were dug approximately 2 weeks earlier than other medium maturity entries for each planting date because of severity of tomato spotted wilt. In 2005 in Marianna, SunOleic 97R was dug and inverted 19 August, 2 September, 19 September, and 7 October. ANorden, Georgia Green, and AP-3 were dug and inverted 2 September, 16 September, 3 October, and 21 October, and DP-1 and C-99R were dug and inverted 16 September, 30 September, 14 October, and 31 October for the four respective planting dates.

At Tifton, Georgia Green and AP-3 were dug based on the average days to maturity for Georgia Green. Digging date was the same for the two cultivars within each planting date and year. At Tifton, dates of digging and inverting both cultivars for the earliest to latest respective planting dates were 3 September, 26 September, and 4 October 2005, 8 September, 18 September, 25 September, 2 October, and 9 October 2006, and 13 September, 24 September, 2 October, 11 October, and 18 October 2007. At all locations, peanuts were harvested mechanically 5 to 11 days after inverting, and pod yields were determined by weighing harvested pods after they were dried and adjusted to $10 \%$ (wt/wt) moisture.

Statistical analysis. Data were analyzed using Proc MIXED with ddfm = satterth option on the model statement (SAS v.9.1, SAS Institute, Cary, NC). Effects were considered significant when $P \leq 0.05$. Fisher's LSD values were computed using standard error and $t$ values of adjusted degrees of freedom. For the experiments conducted in Florida, data were analyzed within each location and year as randomized complete block experiments nested in four planting dates. Planting date and cultivar were considered fixed effects, and replication nested within planting date was 
considered a random effect. When initial analysis indicated a significant planting date $\times$ cultivar interaction, analysis was conducted for each planting date.
For the split-plot experiments at Tifton, analysis was conducted within each year. Planting date and cultivar were considered fixed effects, and replication and replica- tion $\times$ planting date were considered random effects. If the interaction of cultivar and planting date was significant, each factor was compared within individual

Table 1. Effect of peanut cultivar on tomato spotted wilt severity ratings for experiments with different planting dates in Gainesville and Marianna, FL, 2004 and 2005

\begin{tabular}{|c|c|c|c|c|c|c|c|c|c|c|}
\hline \multirow{3}{*}{ Location } & \multirow{3}{*}{ Cultivar } & \multicolumn{9}{|c|}{ Tomato spotted wilt severity ${ }^{a}$} \\
\hline & & \multirow[b]{2}{*}{4 April } & \multicolumn{2}{|c|}{ Planting date 2004} & \multicolumn{5}{|c|}{ Planting date 2005} & \\
\hline & & & 4 May & 25 May & 15 June & & 19 April & 10 May & 2 June & Mean $^{b}$ \\
\hline \multirow[t]{8}{*}{ Gainesville } & ANorden & 2.2 & 2.4 & 4.0 & 3.6 & 4.3 & 4.7 & 4.0 & 5.0 & 4.5 \\
\hline & AP-3 & 2.4 & 2.2 & 2.9 & 3.1 & 3.7 & 3.0 & 2.7 & 5.0 & 3.6 \\
\hline & C-99R & 2.2 & 2.7 & 3.3 & 3.3 & 3.3 & 4.0 & 4.0 & 3.7 & 3.8 \\
\hline & DP-1 & 2.0 & 2.2 & 2.7 & 1.0 & 3.0 & 4.0 & 4.0 & 5.0 & 4.0 \\
\hline & Georgia Green & 2.9 & 3.3 & 4.7 & 4.4 & 2.3 & 3.7 & 3.0 & 3.3 & 3.1 \\
\hline & SunOleic 97R & 3.6 & 4.2 & 4.9 & 5.1 & 5.0 & 5.0 & 4.0 & 3.7 & 4.4 \\
\hline & $\operatorname{LSD}(P \leq 0.05)$ & 0.6 & 0.6 & 0.9 & 1.2 & & & & & 0.8 \\
\hline & & 22 April & 6 May & 20 May & 7 June & 19 April & 4 May & 29 May & 6 June & \\
\hline \multirow[t]{7}{*}{ Marianna } & ANorden & 6.8 & 3.8 & 5.5 & 3.8 & 5.5 & 6.5 & 6.5 & 7.8 & $\ldots$ \\
\hline & AP-3 & 2.3 & 2.0 & 2.0 & 2.0 & 3.5 & 3.0 & 3.8 & 3.3 & $\ldots$ \\
\hline & C-99R & 2.8 & 2.3 & 2.5 & 2.3 & 4.8 & 3.5 & 5.2 & 3.8 & $\ldots$ \\
\hline & DP-1 & 2.3 & 2.5 & 2.2 & 2.2 & 4.0 & 3.0 & 4.8 & 2.8 & $\ldots$ \\
\hline & Georgia Green & 7.5 & 6.0 & 5.0 & 4.2 & 7.2 & 7.0 & 8.3 & 8.0 & $\ldots$ \\
\hline & SunOleic 97R & 8.7 & 8.2 & 7.2 & 5.8 & 8.2 & 8.5 & 9.0 & 7.5 & $\ldots$ \\
\hline & $\operatorname{LSD}(P \leq 0.05)$ & 0.6 & 1.2 & 1.2 & 0.8 & 1.0 & 1.4 & 0.8 & 1.3 & $\ldots$ \\
\hline
\end{tabular}

${ }^{\text {a }}$ Tomato spotted wilt was rated on a plot basis on a 1 to 10 scale with $1=$ no disease and $10=$ all plants severely stunted, wilted, or dead.

b There was no significant interaction between cultivar and planting date. Therefore, cultivars were compared across planting dates.

Table 2. Effect of peanut cultivar on pod yield for experiments with different planting dates in Gainesville and Marianna, FL, in 2004 and 2005

\begin{tabular}{|c|c|c|c|c|c|c|c|c|c|c|}
\hline \multirow{3}{*}{ Location } & \multirow{3}{*}{ Cultivar } & \multicolumn{9}{|c|}{ Pod yield (kg/ha) } \\
\hline & & \multicolumn{4}{|c|}{ Planting date 2004} & \multicolumn{4}{|c|}{ Planting date 2005} & \multirow[b]{2}{*}{ Mean ${ }^{\mathrm{a}}$} \\
\hline & & 4 April & 4 May & 25 May & 15 June & 29 March & 19 April & 10 May & 2 June & \\
\hline \multirow{8}{*}{ Gainesville } & ANorden & 5,674 & 5,114 & 3,235 & 1,645 & 3,828 & 4,832 & 6,823 & 2,042 & 4,381 \\
\hline & AP-3 & 6,451 & 6,686 & 4,445 & 2,060 & 4,224 & 5,684 & 7,477 & 2,996 & 5,095 \\
\hline & C-99R & 5,999 & 4,897 & 4,066 & 1,753 & 5,234 & 4,974 & 8,328 & 3,462 & 5,500 \\
\hline & DP-1 & 5,421 & 6,812 & 5,645 & 1,066 & 4,863 & 6,179 & 7,753 & 2,699 & 5,373 \\
\hline & Georgia Green & 6,288 & 6,794 & 3,126 & 1,771 & 4,066 & 5,670 & 7,628 & 2,334 & 4,924 \\
\hline & SunOleic 97R & 4,326 & 4,716 & 2,891 & 1,265 & 3,328 & 4,618 & 6,440 & 1,482 & 3,967 \\
\hline & $\operatorname{LSD}(P \leq 0.05)$ & 579 & 1,424 & 1,115 & 830 & & & & & 658 \\
\hline & & 22 April & 6 May & 20 May & 7 June & 19 April & 4 May & 29 May & 6 June & \\
\hline \multirow[t]{7}{*}{ Marianna } & ANorden & 2,266 & 3,993 & 4,095 & 2,093 & 2,595 & 2,060 & $1,145^{\circ}$ & 925 & $\ldots$ \\
\hline & AP-3 & 5,486 & 5,883 & 6,573 & 4,716 & 3,751 & 3,611 & 2,366 & 2,244 & $\ldots$ \\
\hline & C-99R & 4,242 & 5,858 & 6,584 & 5,634 & 3,440 & 4,467 & 2,418 & 1,796 & $\ldots$ \\
\hline & DP-1 & 4,658 & 5,049 & 5,985 & 5,204 & 2,761 & 3,317 & 1,864 & 2,259 & $\ldots$ \\
\hline & Georgia Green & 2,425 & 3,725 & 4,669 & 3,357 & 2,317 & 1,872 & 954 & 928 & $\ldots$ \\
\hline & SunOleic 97R & 1,102 & 1,811 & 2,783 & 1,164 & 451 & 697 & 321 & 130 & $\ldots$ \\
\hline & $\operatorname{LSD}(P \leq 0.05)$ & 668 & 840 & 710 & 1,282 & 596 & 697 & 409 & 1,095 & \\
\hline
\end{tabular}

a There was no significant interaction between cultivar and planting date. Therefore, cultivars were compared across planting dates.

Table 3. Linear regression of pod yield on tomato spotted wilt severity ratings across six peanut cultivars, Gainesville and Marianna, FL, 2004 and 2005

\begin{tabular}{|c|c|c|c|c|c|c|}
\hline Year & Location & Planting date & $\begin{array}{c}\text { Intercept } \\
\text { (kg/ha) }\end{array}$ & $\begin{array}{c}\text { Slope of } \\
\text { regression line }\end{array}$ & $P$ & $R^{2}$ \\
\hline 2004 & Gainesville & $\begin{array}{l}4 \text { April } \\
4 \text { May } \\
25 \text { May } \\
15 \text { June }\end{array}$ & $\begin{array}{l}6,945(804)^{\mathrm{a}} \\
7,162(1049) \\
6,347(744) \\
1,610(334)\end{array}$ & $\begin{array}{c}-470(306)^{\mathrm{a}} \\
-464(355) \\
-653(191) \\
-5.0(90)\end{array}$ & $\begin{array}{r}0.15 \\
0.21 \\
\leq 0.01 \\
0.96\end{array}$ & $\begin{array}{r}0.12 \\
0.10 \\
0.42 \\
<0.01\end{array}$ \\
\hline 2005 & Gainesville & $\begin{array}{l}29 \text { March } \\
19 \text { April } \\
10 \text { May } \\
2 \text { June }\end{array}$ & $\begin{array}{l}5,024(440) \\
6,744(1240) \\
7,009(1112) \\
1,593(936)\end{array}$ & $\begin{array}{r}-212(113) \\
-349(299) \\
-111(300) \\
212(210)\end{array}$ & $\begin{array}{l}0.08 \\
0.26 \\
0.72 \\
0.32\end{array}$ & $\begin{array}{r}0.18 \\
0.08 \\
<0.01 \\
0.06\end{array}$ \\
\hline 2004 & Marianna & $\begin{array}{l}22 \text { April } \\
6 \text { May } \\
20 \text { May } \\
7 \text { June }\end{array}$ & $\begin{array}{l}6,233(248) \\
6,867(273) \\
7,748(266) \\
7,408(510)\end{array}$ & $\begin{array}{c}-564(43) \\
-599(58) \\
-649(58) \\
-1,095(139)\end{array}$ & $\begin{array}{c}\leq 0.001 \\
\leq 0.001 \\
0.01 \\
\leq 0.01\end{array}$ & $\begin{array}{l}0.91 \\
0.87 \\
0.89 \\
0.80\end{array}$ \\
\hline 2005 & Marianna & $\begin{array}{l}\text { 19 April } \\
4 \text { May } \\
\text { 29 May } \\
6 \text { June }\end{array}$ & $\begin{array}{l}5,591(476) \\
5,331(381) \\
3,825(350) \\
3,215(478)\end{array}$ & $\begin{array}{l}-549(82) \\
-506(67) \\
-368(53) \\
-330(79)\end{array}$ & $\begin{array}{l}\leq 0.01 \\
\leq 0.01 \\
\leq 0.01 \\
\leq 0.01\end{array}$ & $\begin{array}{l}0.74 \\
0.78 \\
0.75 \\
0.52\end{array}$ \\
\hline
\end{tabular}

\footnotetext{
${ }^{a}$ Numbers in parentheses are standard errors of the respective regression estimates.
} 
levels of the other. Differences were referred to as significant at $P \leq 0.05$ unless otherwise indicated. The relationship between yield and tomato spotted wilt severity or final incidence was evaluated in each year, location, and trial using linear regression.

\section{RESULTS}

Disease assessment and yield. Marianna and Gainesville. Tomato spotted wilt was more severe in Marianna than in Gainesville in both years for Georgia Green, ANorden, and SunOleic 97R, but that trend was not evident in AP-3, C-99R, or DP-1 (Table 1). There were significant planting date $\times$ cultivar interactions for all trials except for the Gainesville location in 2005. In 2004 at Gainesville, tomato spotted wilt ratings were similar for Georgia Green and SunOleic 97R for all trials except the 4 April and 4 May planted trials, where severity was higher in SunOleic 97R than in any other cultivar (Table 1). Severity of tomato spotted wilt was lower in DP-1 than in Georgia Green in all trials, and was lower in AP-3 than in Georgia Green in all trials except the 4 April planted trial (Table 1).

In 2005 at Gainesville, across all planting dates, only Georgia Green and AP-3 had severity ratings that were lower than that of SunOleic 97R (Table 1). Severity ratings for Georgia Green were similar to those of AP-3 and C-99R (Table 1).

In 2004 at Marianna, severity ratings were higher in SunOleic 97R than in any other cultivar in all four trials (Table 1). Severity ratings did not differ among AP-3, C-99R, or DP-1 and were lower in all of those cultivars than in Georgia Green in all four trials (Table 1). With Georgia Green and SunOleic 97R, tomato spotted wilt severity ratings tended to decrease with later planting dates, but there was little indication of association with planting date with spotted wilt severity in AP-3, C-99R, or DP-1 (Table 1).

In 2005 at Marianna, severity ratings were higher in SunOleic 97R than in any other cultivar in the 19 April and 4 May planted trials, but were similar to those of Georgia Green in the later planted trials (Table 1). Tomato spotted wilt was severe in both of these cultivars across all trials. Severity ratings in AP-3, C-99R, and DP-1 were lower than those in Georgia Green in all four trials (Table 1).

There were significant $(P \leq 0.05)$ planting date $\times$ cultivar effects on pod yield for all trials except the 2005 experiment at Gainesville. Therefore, independent analyses were conducted for each planting date in all other experiments.

In 2004 at Gainesville, yields were higher for Georgia Green than for SunOleic 97R in the 4 April and 4 May planted trials, but were similar in the 25 May and 15 June planted trials (Table 2). Yields of AP-3 were similar to those of Georgia Green in all trials except the 25
May planted trial (Table 1), but the relative performances of C-99R and DP-1 compared to AP-3 and Georgia Green were variable across the trials. There was a gen- eral trend toward decreased yields with the 25 May planting date compared to earlier plantings, and yields for all cultivars were low for the 15 June planting. In 2005 at
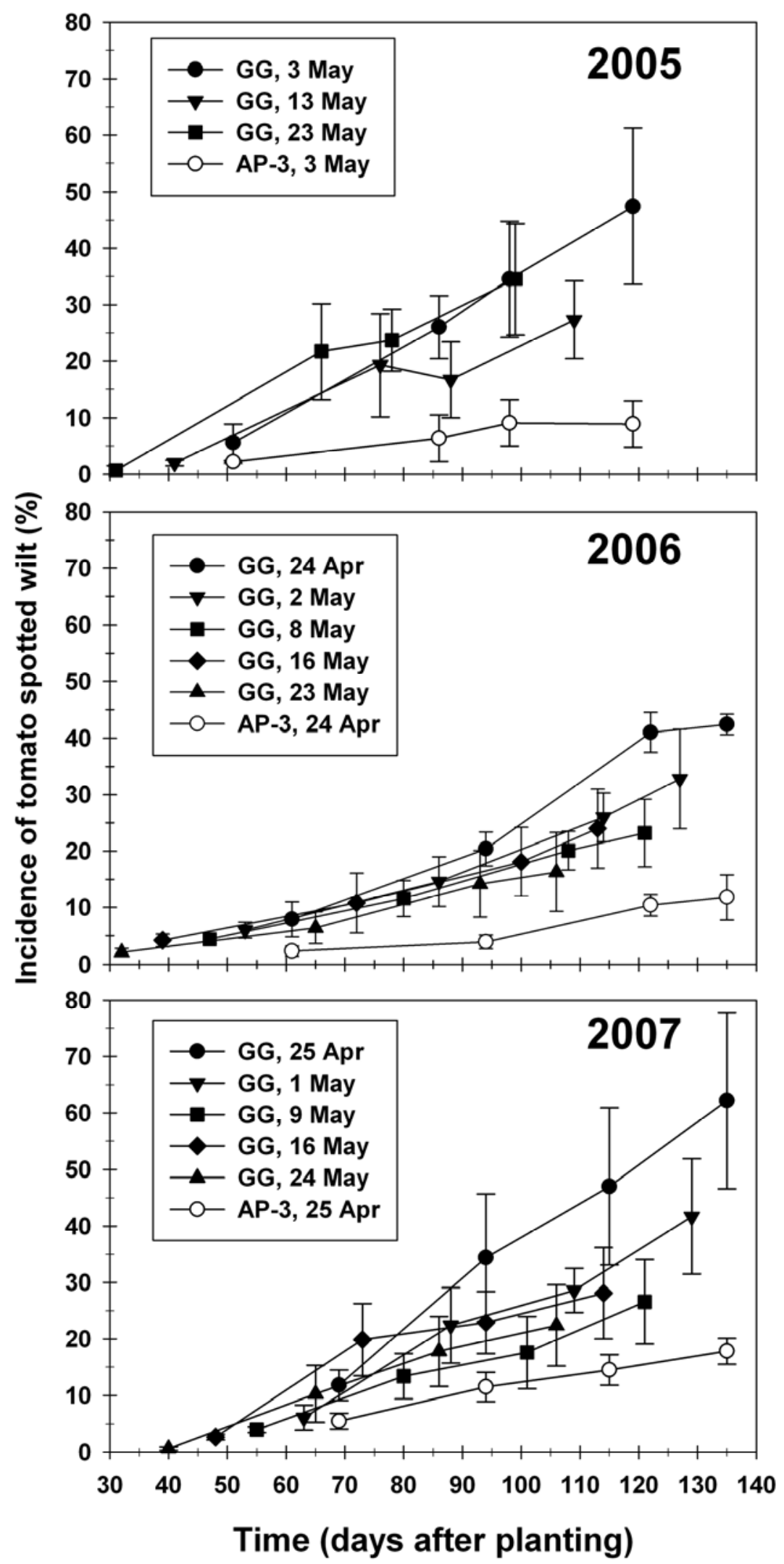

Fig. 1. Disease progress of tomato spotted wilt in Georgia Green (GG) planted across a range of planting dates compared to disease progress in AP-3 for the initial planting dates, Tifton, GA, 2005 to 2007. Error bars are standard deviations of the respective means. 
Gainesville, across planting dates, yields were similar for SunOleic 97R and ANorden. All other cultivars had higher yields than SunOleic 97R, and only SunOleic
97R had yield that differed from that of Georgia Green (Table 2).

In 2004 at Marianna, yields of SunOleic $97 \mathrm{R}$ were lower than those of any other

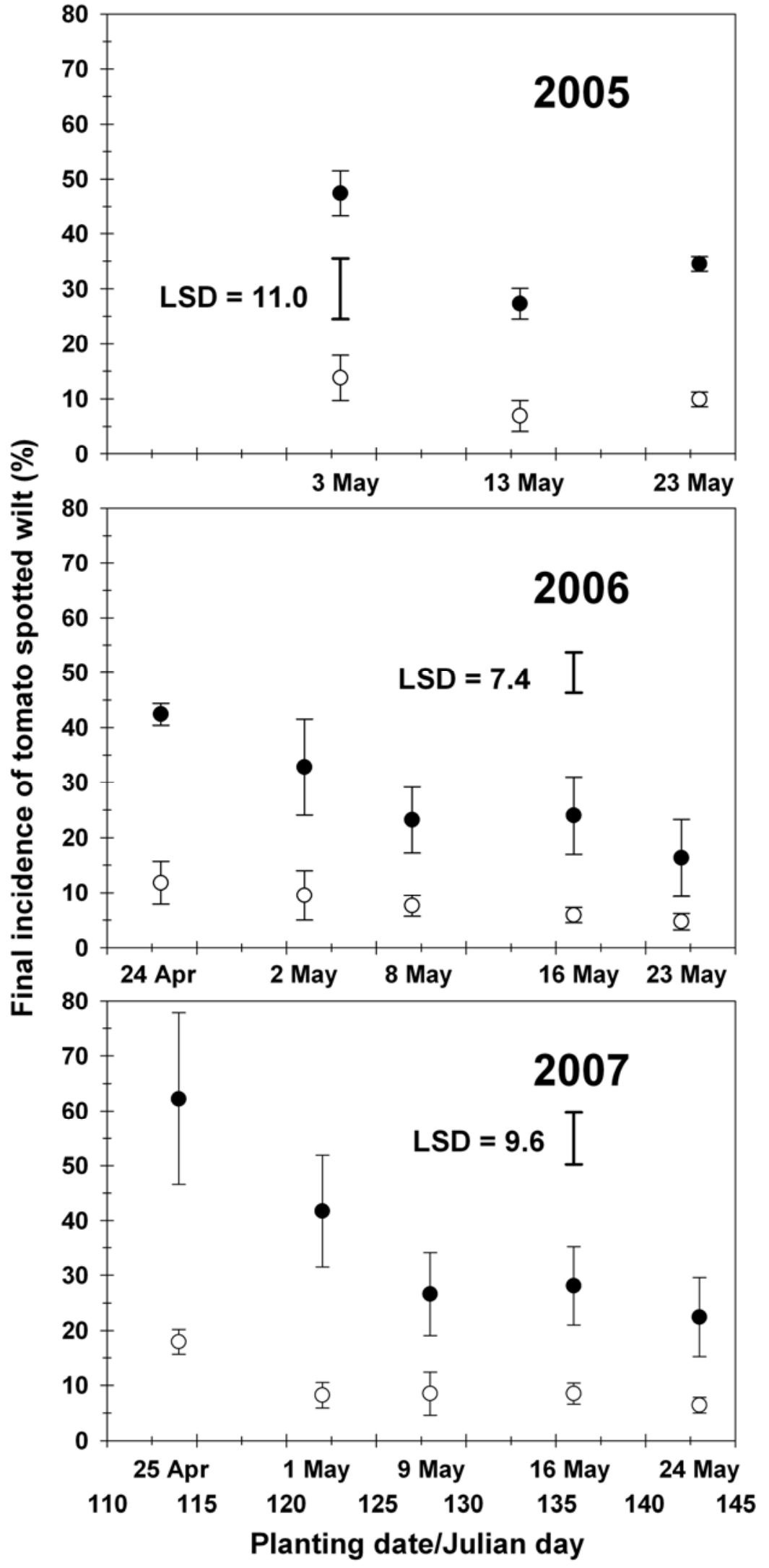

Fig. 2. Effect of planting date on final incidence of tomato spotted wilt in Georgia Green (closed circles) and AP-3 (open circles) peanut cultivars, Tifton, GA, 2005 to 2007. Error bars are standard deviations of the respective means. cultivar (Table 2). Yields of AP-3, C-99R, and DP-1 were higher than those of Georgia Green in all trials (Table 2). Yields were low for most cultivars at Marianna in 2005. Yields were lowest in SunOleic 97R in all trials except the 6 June planted trial (Table 2). In that trial, yield of SunOleic 97R was particularly low, but yields did not differ among SunOleic 97R, Georgia Green, or ANorden (Table 2). Yields of AP-3 were higher than those of Georgia Green in all trials (Table 2). Yields of C99R were higher than those of Georgia Green in all but the 6 June planted trial, and yields of DP-1 were higher than those of Georgia Green in all but the 19 April planted trial.

Yield ( $\mathrm{kg} / \mathrm{ha}$ ) decreased linearly with increase in tomato spotted wilt severity ratings for the 25 May planted trial in 2004 (Table 3). There was no other significant regression $(P \geq 0.08)$ between tomato spotted wilt severity and yield in any other trial in Gainesville. Yield decreased linearly with increase in tomato spotted wilt severity for all trials at Marianna (Table 3).

Tifton. Spotted wilt was more severe in 2005 and 2007 than in 2006 (Figs. 1 and 2 ). Disease progress of incidence of tomato spotted wilt over time in days after planting was plotted for all planting dates for Georgia Green and the initial planting date for AP-3 (Fig. 1). Disease progress curves of tomato spotted wilt for AP-3 planted at the earliest planting differed greatly from those for Georgia Green planted at the same date, and were at a similar level or below that of disease progress curves for Georgia Green for any other planting date (Fig. 1).

There were significant interactions $(P \leq$ 0.05 ) between planting date and cultivar for final incidence of spotted wilt in all years and for yield in 2005 and 2007. In 2005 , cultivar and planting date $\times$ cultivar interaction effects were significant for final incidence of tomato spotted wilt, but planting date main effects were not $(P>0.12)$. Final incidence of spotted wilt in Georgia Green was similar for the 13 May and 23 May planting dates, and higher in the 3 May planting date than for the 13 May and 23 May planting dates (Fig. 2). There was no planting date effect on incidence of spotted wilt in AP-3 (Fig. 2).

In 2006 and 2007, planting date, cultivar, and planting date $\times$ cultivar effects were significant $(P<0.05)$ for final incidence of spotted wilt. Final incidence of tomato spotted wilt was lower for AP-3 than for Georgia Green within all planting dates in 2006 and 2007 (Fig. 2). In both years, final incidence of tomato spotted wilt in AP-3 for the April planting dates was similar to that of the latest planting date for Georgia Green (Fig. 2). In both 2006 and 2007, final incidence of tomato spotted wilt in Georgia Green was highest for the earliest planting date and higher for the second planting date than for any other 
(Fig. 2). Incidence in Georgia Green was similar among the final three planting dates in both years (Fig. 2). In 2006, there was no planting date effect on incidence of tomato spotted wilt in AP-3 (Fig. 2). In 2007, incidence of tomato spotted wilt in AP-3 was highest for the 25 April planting date, but there were no differences among the other planting dates (Fig. 2).

In 2005, cultivar and planting date $\times$ cultivar interaction effects were significant $(P \leq 0.05)$ for yield, but planting date main effects were not $(P>0.10)$. Yields were higher in AP-3 than in Georgia Green for the 3 May and 23 May planting dates, but were similar for the two cultivars for the 13 May planting date (Fig. 3).

In 2006, planting date and cultivar main effects were significant for yield, but the planting date $\times$ cultivar interaction was not significant $(P>0.17)$. Across planting dates, yield was $3,146 \mathrm{~kg} / \mathrm{ha}$ for Georgia Green and 4,668 kg/ha for AP-3 (LSD = $269 \mathrm{~kg} / \mathrm{ha}, P \leq 0.05$, df $=15$ ). In 2006 , yields pooled across cultivars were higher for the second, third, and fourth planting dates than for the first or fifth planting dates (Fig. 3). In 2007, planting date, cultivar, and planting date $\times$ cultivar effects were significant $(P \leq 0.05)$ for yield. Yields were higher for AP-3 than for Georgia Green within all planting dates (Fig. 3). Yields of both cultivars were lowest for the fourth planting date (Fig. 3).

Yield (kg/ha) decreased linearly with increasing percent incidence of tomato spotted wilt (TSWI) according to the functions:

2005 Yield $(\mathrm{kg} / \mathrm{ha})=4,538( \pm 192)-32.8( \pm 7.2)$

* TSWI, $\left(P<0.01, R^{2}=0.49\right)$

2006 Yield $(\mathrm{kg} / \mathrm{ha})=4,775( \pm 224)-50.7( \pm 10.7)$

* TSWI, $\left(P<0.01, R^{2}=0.37\right)$

2007 Yield $(\mathrm{kg} / \mathrm{ha})=5,403( \pm 246)-33.0( \pm 8.7)$

* TSWI, $\left(P<0.01, R^{2}=0.27\right)$

\section{DISCUSSION}

Results from these experiments illustrate the importance of location effects on levels of tomato spotted wilt and relative performance of cultivars with different levels of field resistance. Although tomato spotted wilt epidemics occurred in both years at the Gainesville site, they were much less severe than those observed at Marianna and Tifton. This trend is consistent with previous observations, but has not been conclusively explained. In Gainesville, factors other than management of tomato spotted wilt would be the primary considerations for choice of both cultivar and planting date.

Observations at Marianna and Tifton corroborate previous reports of less severe epidemics of tomato spotted wilt in C-99R (21), DP-1 $(6,12,15)$, and AP-3 $(9,12,19)$ than in Georgia Green, and the relative weighting for these cultivars on the tomato spotted wilt risk index $(3,4)$. Across two experiments planted in mid-April in 1998 (12), final incidence of tomato spotted wilt in AP-3 and Georgia Green were very similar to the respective incidences for those two cultivars for the earliest planting dates at Tifton in this study. Across multi- ple experiments at Marianna in 2001 to 2004 (19) and at Tifton in 2006 and 2007 (9) which utilized mid-April to early May planting dates, incidence or severity of

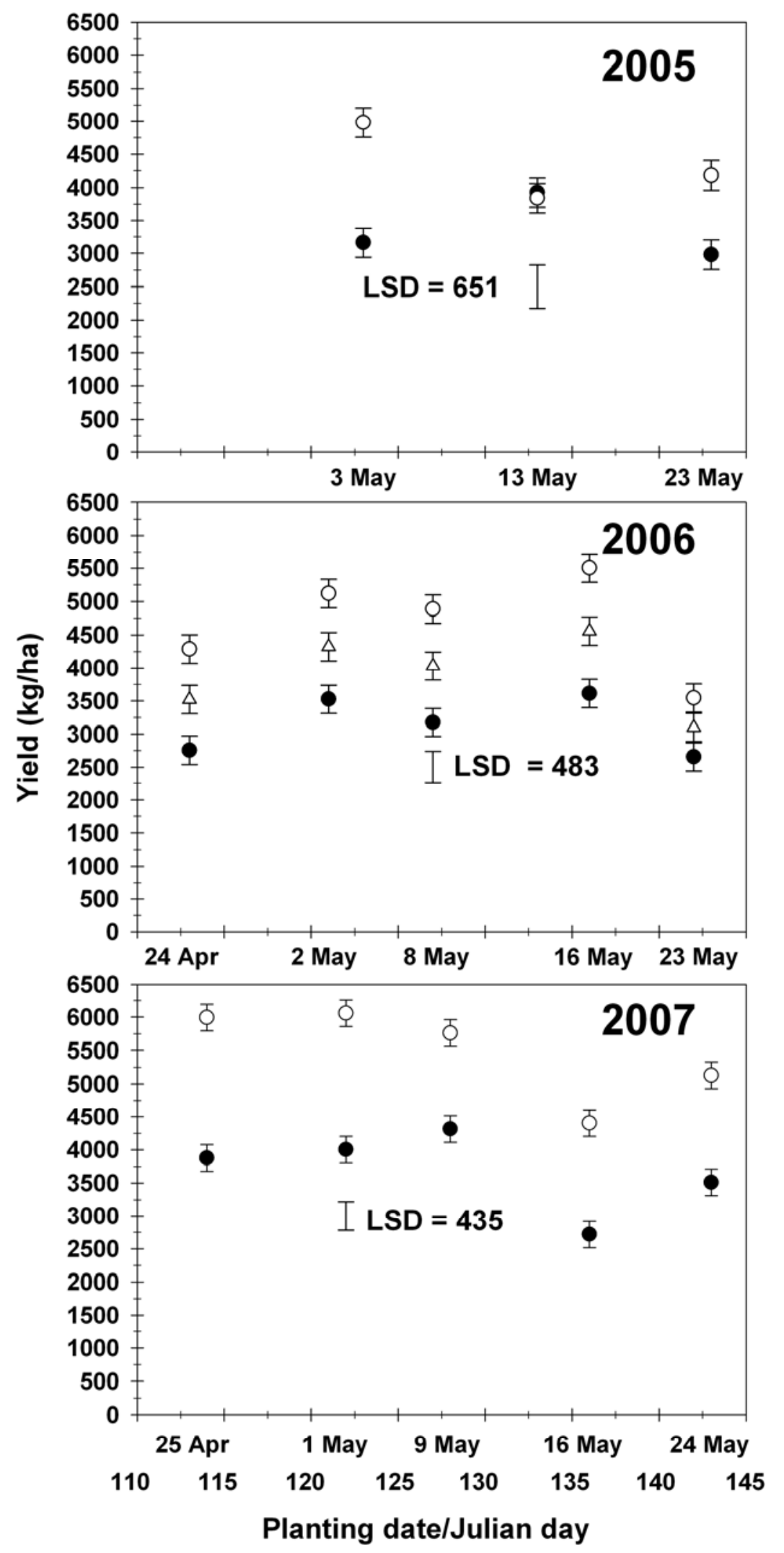

Fig. 3. Effect of planting date on pod yield in Georgia Green (GG) (closed circles) and AP-3 (open circles) peanut cultivars, Tifton, GA, 2005 to 2007. In 2006, there was no significant planting date $\times$ cultivar interaction; therefore, planting dates were compared across cultivars (open triangles). Error bars are standard deviations of the respective means. 
tomato spotted wilt in AP-3 was consistently lower than in Georgia Green.

The results for Georgia Green and SunOleic 97R in 2004 at Marianna, and for Georgia Green in 2006 and 2007 at Tifton, corroborate previous observations that peanut planted in April or early May typically has higher incidence of spotted wilt than those planted later in May $(4,5,10,16,17)$. In contrast, severity of tomato spotted wilt was high across planting dates for Georgia Green and SunOleic 97R at Marianna in 2005, and there was a trend toward higher severity for late May and June plantings of these cultivars and ANorden than for the April planting. In trials where planting date effects were observed in Georgia Green, there was less evidence of planting date effect on incidence or severity of tomato spotted wilt in AP-3 and DP-1 than in Georgia Green. The highest incidence of spotted wilt in AP-3 in the earliest planting dates in 2006 and 2007 were similar to, although numerically lower than, the incidence in Georgia Green in the optimum planting date observed in those experiments.

Results from Marianna and Tifton indicate that high levels of field resistance to TSWV may be required to maximize yields when potential for spotted wilt is high. However, several practices used in this study, such as use of single row patterns, conventional tillage, and no infurrow insecticide applications, typically increase the potential for severe spotted wilt epidemics (10). Factors other than cultivar and planting date that suppress tomato spotted wilt were not examined in this study. Use of as many suppressive factors as possible can be essential with a moderately resistant cultivar such as Georgia Green, and use of other management practices should further reduce risk of losses to tomato spotted wilt in more highly resistant cultivars. However, with highly resistant cultivars, other factors are not as critical. In another study in which April planting dates were used, effects of phorate insecticide or twin-row patterns on incidence of tomato spotted wilt were much greater for Georgia Green than for AP-3 and several other cultivars with high levels of field resistance (9). Results from this study indicate that the field resistance to tomato spotted wilt in AP-3 or DP-1 is also sufficient to allow greater versatility in choosing planting dates without greatly increasing the risk of losses to tomato spotted wilt than is indicated for Georgia Green using similar production practices. Several other cultivars with levels of field resistance similar to that of AP-3 (9) may likewise allow use of earlier planting dates.
Trends in effects of planting date on tomato spotted wilt were not consistently reflected in yield. With different harvest times, yield effects of planting date or cultivars with different times to maturity can be confounded with environmental conditions during the time of digging, drying, and harvest. Heavy rains late in the season at Gainesville were likely responsible for reduced yields for the June planted trials in both years at that location. Cultivar effects on yield at Marianna and Tifton were much more consistent than at Gainesville, likely due to differences in severity of tomato spotted wilt epidemics at the three locations. Yields were greater for AP-3 than for Georgia Green for most planting dates at Tifton in all 3 years, and for all eight trials in Marianna.

Use of cultivars such as AP-3 or DP-1 with greater field resistance to TSWV than Georgia Green should allow extension of the planting season into late April without greatly increasing the risk of losses to tomato spotted wilt, especially if combined with other factors that help suppress tomato spotted wilt.

\section{ACKNOWLEDGMENTS}

We thank Michael Heath, Stephanie Danforth, Ron Hooks, Allison McKeown, Kacie Parrish, Jonathan Roberts, and Kevin Welch for their field assistance. This research was supported in part by growers through grants from the Florida Peanut Producers Association, the Georgia Peanut Commission, and the National Peanut Board.

\section{LITERATURE CITED}

1. Branch, W. D. 1996. Registration of 'Georgia Green' peanut. Crop Sci. 36:806.

2. Branch, W. D., Baldwin, J. A., and Culbreath, A. K. 2003. Genotype $\times$ seeding rate interaction among TSWV-resistant, runner-type peanut cultivars. Peanut Sci. 30:108-111.

3. Brown, S., Todd, J., Culbreath, A., Beasley, J., Kemerait, B., Prostko, E., Brenneman, T., Smith, N., Paz, J., Olatinwo, R., Tillman, B., Gorbet, D., Weeks, R., and Hagan, A. 2008. Minimizing Diseases of Peanuts in the Southeastern United States: The 2008 Versions of the Peanut Disease Risk Index. Pages 36-52 in: 2008 Peanut Update. E. Prostko, ed. University of Georgia, Cooperative Extension Service, Athens, GA. Publ. CSS-08-0114.

4. Brown, S. L., Culbreath, A. K., Todd, J. W., Gorbet, D. W., Baldwin, J. A., and Beasley, J. P., Jr. 2005. Development of a method of risk assessment to facilitate integrated management of spotted wilt of peanut. Plant Dis. 89:348352.

5. Brown, S. L., Todd, J. W., and Culbreath, A. K. 1996. Effect of selected cultural practices on incidence of tomato spotted wilt virus and populations of thrips vectors in peanuts. Acta Hortic. 431:491-498.

6. Cantonwine, E. G., Culbreath, A. K., Stevenson, K. L., Kemerait, R. C., Jr., Brenneman, T. B., Smith, N. B., and Mullinix, B. G., Jr. 2006. Integrated disease management of leaf spot and spotted wilt of peanut. Plant Dis. 90:493-500.

7. Culbreath, A., Beasley, J., Kemerait, B.,
Prostko, E., Brenneman, T., Smith, N., Tubbs, S., Paz, J., Olatinwo, R., Tillman, B., Gorbet, D., Weeks, R., and Hagan, A. 2009. Peanut $\mathrm{R}_{\mathrm{x}}$ : Minimizing diseases of peanut in the southeastern United States, the 2009 version of the peanut disease risk index. Pages 36-51 in: 2009 Peanut Update. E. Prostko, ed. University of Georgia Cooperative Extension Service, Athens, GA.

8. Culbreath, A. K., Gorbet, D. W., MartinezOchoa, N., Holbrook, C. C., Todd, J. W. Isleib, T. G., and Tillman, B. L. 2005. High levels of field resistance to Tomato spotted wilt virus in peanut breeding lines derived from hypogaea and hirsuta botanical varieties. Peanut Sci. 32:20-24.

9. Culbreath, A. K., Tillman, B. L., Gorbet, D. W., Holbrook, C. C., and Nischwitz, C. 2008. Response of new field-resistant peanut cultivars to twin-row pattern or in-furrow applications of phorate for management of spotted wilt. Plant Dis. 92:1307-1312.

10. Culbreath, A. K., Todd, J. W., and Brown, S. L. 2003. Epidemiology and management of tomato spotted wilt in peanut. Annu. Rev. Phytopathol. 41:53-75.

11. Culbreath, A. K., Todd, J. W., Brown, S. L., Baldwin, J. A., and Pappu, H. 1999. A genetic and cultural package for management of tomato spotted wilt virus in peanut. Biol. Cult. Tests Control Plant Dis. 14:1-8.

12. Culbreath, A. K., Todd, J. W., Gorbet, D. W., Brown, S. L., Baldwin, J. A., Pappu, H. R., Holbrook, C. C., and Shokes, F. M. 1999. Response of early, medium, and late maturing peanut breeding lines to field epidemics of tomato spotted wilt. Peanut Sci. 26:100-106.

13. Culbreath, A. K., Todd, J. W., Gorbet, D. W., Shokes, F. M., and Pappu, H. R. 1997. Field response of new peanut cultivar UF 91108 to tomato spotted wilt virus. Plant Dis. 81:14101415.

14. Gorbet, D. W. 2007. Registration of 'AP-3' peanut. J. Plant Registr. 1:126-127.

15. Gorbet, D. W., and Tillman, B. L. 2008. Registration of 'DP-1' peanut. J. Plant Registr. 2:200-204.

16. Hurt, C. A., Kennedy, G. G., Bailey, J. E. Brandenburg, R. L., and Jordan, D. L. 2005. Management of spotted wilt vectored by Frankliniella fusca (Thysanoptera: Thripidae) in virginia market-type peanut. J. Econ. Entomol. 98:1435-1440.

17. McKeown, S. P., Todd, J. W., Culbreath, A. K., Gorbet, D. W., and Weeks, J. R. 2001. Planting date effects on tomato spotted wilt in resistant and susceptible peanut cultivars. (Abstr.) Phytopathology 91:S60.

18. Tillman, B. L., Gorbet, D. W., and Anderson, P. C. 2007. Influence of planting date on yield and spotted wilt of runner market type peanut. Peanut Sci. 34:79-84

19. Tillman, B. L., Gorbet, D. W., Culbreath, A. K., and Todd, J. W. 2006. Response of peanut cultivars to seeding density and row patterns. Crop Manag. doi:10.1094/CM-2006-0711-01RS.

20. Todd, J. W., Culbreath, A. K., and Brown, S. L. 1996. Dynamics of vector populations and progress of spotted wilt disease relative to insecticide use in peanuts. Acta Hortic. 431:483490.

21. Wells, M. L., Culbreath, A. K., Todd, J. W., Brown, S. L., and Gorbet, D. W. 2002. A regression approach for comparing field resistance of peanut cultivars to tomato spotted wilt tospovirus. Crop Prot. 21:467-474. 